\title{
Supervisor Incivility and Employee revenge: the Role of Hostile Attribution
}

\author{
Jie HUANG \\ Hunan University of Commerce \\ Chang-e LIU \\ Wei XIE Yahui CHEN \\ School of Business \\ Mobile E-business Collaborative Innovation Center of Hunan Province \\ Key Laboratory of Hunan Province for Mobile Business Intelligence \\ Hunan University of Commerce Changsha, China
}

\begin{abstract}
Research to date has largely been unclear about the relationship between supervisor incivility and employee revenge. In the current research, based on the negative norm of reciprocity, we examine the extent to which hostile attribution moderates the relationship between supervisor incivility and employee revenge. Collecting 319 employee's data, we show that supervisor incivility is associated with employee revenge. Moreover, we find that hostile attribution moderates the main effect positively, such that the higher employees with hostile attribution, the stronger the association between supervisor incivility and employee revenge; the lower employees with hostile attribution, the weaker the association between supervisor incivility and employee revenge; Implications for theory and practice are discussed.
\end{abstract}

Keywords: Supervisor incivility; Employee revenge; Hostile attribution; Norm of reciprocity

\section{Introduction}

The research shows that workplace incivility is widespread among the USA organizations and becomes a significant source of stress for employees (Cortina et al., 2001; Cortina \& Magley, 2009). Comparing with the western countries, China is the state of Confucian culture, which emphasizes on "harmony", "zhongyong" and "face". People are more engaged in workplace incivility than other different destructive behaviors such as deviant behavior, aggressive behavior. Empirical studies have found that workplace incivility is prevalent in Chinese organization, especially supervisor incivility. Supervisor incivility is discourteous behavior from a supervisor that is targeted at a subordinate, is usually low intensity, and has ambiguous intent to harm (Anderson \& Pearson, 1999). This deviant and rude behavior from supervisors is associated with negative personal and organizational costs. Exposure to supervisor incivility at work is associated with reduced physical health (Lim et al., 2008) and job satisfaction (Liu et al., 2011) and organization performance (Caza \& Cortina, 2007) and increased depression (Lim \& Lee, 2011; Miner et al., 2012) and turnover intention (Liu et al., 2017b) and creativity (Liu et al., 2018). Moreover, the impacts of supervisor incivility can spill over into employees' personal lives, leading to increased work-family conflict (Lim \& Lee, 2011), and reduced marital satisfaction (Ferguson, 2012).

In particular, recent studies find that experiencing incivility is associated with engaging in revenge, such as taking long breaks, doing work incorrectly, or engaging in interpersonal hostility (Penney \& Spector, 2005; Porath \& Pearson, 2013; Sakurai \& Jex, 2012). Revenge refers to an action in response to some perceived wrongdoing by another party that is intended to inflict damage, injury, discomfort, or punishment on the party judged responsible (Aquino, Tripp, \& Bies, 2001; Frijda, 1994). Revenge can be either active, in the form of directing harm toward another person, or passive, in the form of withholding support (Ferrari \& Emmons, 1994; Miller, 2001). 
Additionally, it is usually the victim of the initial harm who seeks revenge. Such behavior may be organizationally or interpersonally targeted (Robinson \& Bennett, 1995) and can include interpersonal abuse, production deviance and sabotage, theft, and withdrawal (Spector et al., 2006). Revenge can be extremely costly for organizations, leading to substantial financial losses (Coffin, 2003; Vardi \& Weitz, 2004).

Given these organizational repercussions, it is critical for companies to be aware of employees to engage in revenge in response to the experience of supervisor incivility. Yet only a few studies have explored the relationship between incivility and revenge (e.g., Sakurai \& Jex, 2012; Sliter et al., 2012). Further, due to the nascent stage of this area of research, little is known about the conditions that either strengthen or weaken the relationship between these constructs. Based on norm of reciprocity, we aim to examine the extent to which the expected relationship between supervisor incivility and revenge is moderated by condition of hostile attribution in the current research. We focus our study on hostile attribution because it has the potential to heighten employee responses to supervisor incivility (Liu et al., 2017a). hostile attribution refers to individuals automatic and longterm hostile interacting with others, which includes denigrating, resenting, negative comments and opinions on others. It has a negative impact on employee behavior, and will reduce the belongingness, psychological security and identification with supervisor (Cortina, 2001). Meanwhile, employees with hostile attribution will invest more resources to cope with supervisor incivility so as to beat even.

We propose that employees who are highly hostile attribution will experience a stronger stressor-strain relationship between supervisor incivility and revenge, such that they are more likely to respond to supervisor incivility with revenge, compared to employees with low level of hostile attribution. In the following section, we develop the theoretical background and basis for our hypotheses. We then present the methodology and results of our study, and discuss its theoretical and practical implications.

\section{Literature Review and Hypotheses}

\subsection{The effect of supervisor incivility on employee revenge}

Gouldner (1960) in a classic article postulated a generalized positive norm of reciprocity, stipulating that (1) people should help those who have helped them, and (2) people should not harm those who help them. Extending this premise, Helm, Bonoma, and Tedeschi demonstrated that a negative norm of reciprocity exists: the " frequency of reciprocated (counter aggression) was a direct and linear function of frequency of initial aggression delivered" (1972,97). Further, they found that when initial aggression is perceived by the target as unprovoked, the target employs counter aggression for revenge, rather than as a counter deterrence. According to the negative norm of reciprocity, when the subordinates are subjected incivility from their supervisors, they will employ incivility or other severe deviant behavior as a reciprocity. If they think the revenge can't cause consequence, they will be in revenge toward their supervisors. If they think their revenges toward supervisor lead to severe outcomes, they will direct harm toward coworkers or organizations because the supervisors are the "face" of the organization. In China, the subordinates usually retaliate their supervisors implicitly because of power distance.

Studies have shown that supervisor incivility has positive relationship with organizational-oriented employee revenge (destruction and theft of corporate property, negative absenteeism, and handling private affairs during working hours). Tepper et al. (2006) found that when employee acquiescence revenge and show more revenge behavior, perceived supervisor incivility will affect employee revenge behavior through subordinate emotional commitment. Dupre et al. (2006) pointed out that supervisor incivility can cause employees to produce superiorlevel retaliation, but the purpose of the work can adjust the relationship between supervisor incivility and revenge. If the employee's job is to obtain an economic source, the relationship will be stronger; if the employee's job is to achieve his own value, the relationship will be weakened. Mitchell et al. (2010) considered that supervisor incivility is an aggression, and the negative feedback principle regulates the positive relationship between supervisor incivility and superior-level employee revenge, which means that when the employee suffers from supervisor incivility, they will directly retaliate against the superior or organization. Therefore, we predict that:

Hypothesis 1: Supervisor incivility has positive relationship with employee revenge.

\subsection{The moderating effect of hostile attribution}

It is a long-term concern in organization behavior that how employees' perceptions of supervisors affect their attitudes and behaviors. In common, employee's attribution to motivation of supervisor incivility is very important to their behaviors. The employee with high hostile attribution regards supervisor incivility as malicious harm, while the employee with low hostile attribution treats supervisor incivility as promoting performance. 
According to negative norm of reciprocity, if individuals attribute supervisor incivility as malicious harm, they will fight back against the supervisor and organization in proportion. This attribution will increase employee revenge. On the contrary, if individuals attribute supervisor incivility as promoting their performances, they will have less negative emotion and take less retaliation. Hostile attribution may moderate the association between supervisor incivility and employee revenge.

Zhang (2009) believes that when suffered from supervisor incivility, the employee will use information processing to discern the intention of the superior behavior. When employees attribute the motivation of supervisor incivility to harming themselves, they will consider such supervisor incivility to be immoral. In this situation, employees will form various negative emotions, lose interest in work and reduce job performance, and even produce biased behavior. Guan (2014) believes that employees will resist such unethical and harmful behaviors of supervisors by retaliating. It can be seen that employee's hostile attribution to supervisor incivility will aggravate the positive effect of the relationship between supervisor incivility and employee revenge. Therefore, we predict that:

Hypothesis 2: hostile attribution will moderate the relationship between supervisor incivility and employee revenge. such that the positive relationship will be stronger when the employee with high hostile attribution compared to the employee with low hostile attribution. Based on the above analysis, this research establishes conceptual model in follow figure 1 .

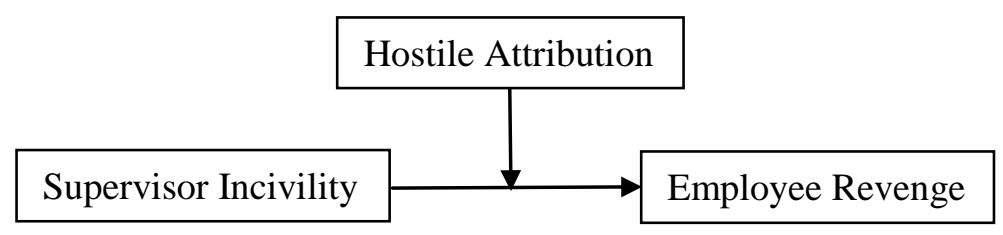

Figure 1 Conceptual model

\section{Research Design}

\subsection{Sample and data-collection procedure}

The sample of this study mainly comes from eight private company's employees in Hunan province of China. In 2018, we received a total of 380 responses using electronic and papery questionnaires, attaining 319 valid data, and the validity questionnaire rate was $83.9 \%$. 121 respondents $(37.93 \%)$ were men. The age of participants ranges from 20 to 50(M=32.79). 217 respondents $(68.02 \%)$ were employees, 62 respondents $(19.43 \%)$ were supervisors, and 40 respondents(12.53\%) were senior managers. With regarded to education, 227 respondents were undergraduates $(71.15 \%), 16$ respondents were masters or doctors $(5.01 \%)$. With regarded to work seniority, 201 respondents have been working less than one year(63.00\%), 76 respondents have been working 1-3 years(23.82\%), 34 respondents have been working 3-5 years(10.65\%), 8 respondents have been working over 5 years $(2.51 \%)$.

\subsection{Measures}

In order to ensure the reliability of measurement tools, we used the mature scales which other researchers have developed. All scales were scored by Likert 5 points (1= "strongly disagree"; $5=$ "strongly agree"). All scales in this study are described as following.

(1) Supervisor Incivility. Supervisor incivility was measured by Liu and Dai (2012), modifying the original scale developed by Cortina and Magley (2001), which consisted of twelve items that gauge the frequency with which the respondents experienced workplace incivility in dealing with supervisor during the past time. Sample items include "My supervisor put me down or was condescending to me" and "My supervisors made demeaning or derogatory remarks about me." and so on. Cronbach's $\alpha$ for this scale was .913.

(2) Employee Revenge. Seventeen items from the employee revenge Questionnaire (Skarlicki,\&Folge,1997) were used to measure employees' retaliation from work. Participants were asked to indicate to what degree items reflected their retaliation during past time on a 5-point scale ranging from 1 (strongly disagree) to 5 (strongly agree). Example items include "I damaged company's property" and "I disobeyed supervisor". Cronbach's $\alpha$ for this scale was .936 .

(3) Hostile attribution. Seven items referred to hostile attribution, an example of which is "My supervisor wanted to hurt my feelings." and "My supervisor wanted me to feel bad". 
Response options ranged from 1 (very seldom or never) to 5 (very often or always). Participants were asked to indicate how frequently they had experienced each indicator over the past time. Cronbach's $\alpha$ for this scale was .921.

(4)Control Variables. We controlled for respondents' demographic variables, including gender, age, position, education and work seniority in the organization. As previous research suggested that these variables affect employees' behavior (Thau et al., 2009). To ensure the accuracy of the results, these variables are controlled.

\section{Results}

\subsection{Descriptive statistics and correlation analysis}

Descriptive statistics and bivariate correlations for all study variables are reported in Table 1. In line with past research, supervisor incivility $(r=.772, p<.01)$ were positively associated with Hostile attribution, respectively. Supervisor incivility, $r=.549, p<.01$, and Hostile attribution, $r=.648, p<.01$, were positively associated with employee revenge.

Table 1 Descriptive Statistics and Correlations

\begin{tabular}{cccccccccc}
\hline Variable & $\mathbf{M}$ & SD & $\mathbf{1}$ & $\mathbf{2}$ & $\mathbf{3}$ & $\mathbf{4}$ & $\mathbf{5}$ & $\mathbf{6}$ & $\mathbf{7}$ \\
\hline 1.gender & 1.62 & .486 & & & & & & & \\
2.age & 2.11 & .448 & .005 & & & & & & \\
3.position & 1.22 & .581 & -.090 & .048 & & & & & \\
4.education & 1.81 & .437 & .048 & $-.164^{* *}$ & .029 & & & & \\
5 work seniority & 1.03 & .207 & -.006 & $-.300^{* *}$ & $.125^{*}$ & -.039 & & & \\
6.Supervisor incivility & 1.81 & .705 & -.099 & -.055 & -.010 & $.169^{* *}$ & -.039 & & $.032^{* *}$ \\
7.Hostile attribution & 1.54 & .741 & -.093 & -.028 & -.001 & $.121^{*}$ & -.034 & $.772^{* *}$ \\
8.Employee revenge & 1.66 & .728 & $-.119^{*}$ & -.052 & -.056 & .054 & -.032 & $.549^{* *}$ & $.648^{* *}$ \\
\hline
\end{tabular}
Note. ${ }^{* \star} \mathrm{p}<0.001 ;{ }^{* *} \mathrm{p}<0.01 ;{ }^{*} \mathrm{p}<0.05 ;$ the same below.

\subsection{Common method bias}

To ensure the results, this study used harman single factor to analyze data. This study made un scaled principal component analysis for all variables (Zhou \& Long, 2004). According to the number of factor precipitation or common factor interpretation to determine the size of the common method of deviation, in this study, seven common factors (eigenvalue $>1$ ) were extracted from the test results, and the first factor explained variation is $17.57 \%$, less than $50 \%$ (recommended explained variation). It indicated that bias problem of the common method was not serious.

\subsection{Reliability and validity analysis}

The study uses SPSS21.0 statistical analysis software to analyze the reliability and validity of scales. The results are shown in table 2. Cronbach alpha coefficients of all scales were above 0.90 , indicating that the reliability of the scale is quite high. The KMO values of each scale were all greater than 0.60 , and the results of Bartlett spherical test were significant, and each scale cumulative variances were greater than $50 \%$, indicating good validity.

Table 2 Reliability and Validity Analysis

\begin{tabular}{cccc}
\hline Variable & Cronbach's Alpha & KMO & Cumulative Interpretation Variance \\
\hline supervisor incivility & 0.913 & 0.842 & $62.7 \%$ \\
Hostile attribution & 0.921 & 0.851 & $80.3 \%$ \\
Employee revenge & 0.936 & 0.827 & $71.2 \%$ \\
\hline
\end{tabular}

Confirmatory factor analyses were conducted to justify the examination of supervisor incivility (SI), hostile attribution (HA) and employee revenge(ER) as independent constructs. Regarding the former comparison, The results show that the three-factor model assumed in this study has reached the acceptance criteria $(\mathrm{X} 2 / \mathrm{df}=1.621<2$, RMSEA $=0.065<0.08$, IFI, TLI, CFI are greater than 0.9). The results of these confirmatory factor analyses indicate three variables have good convergent validity and discriminant validity. 
Table 3 Confirmatory Factor Analyses

\begin{tabular}{ccccccc}
\hline Model & Factor & $\mathbf{X}^{2} / \mathbf{d f}$ & RMSEA & IFI & TLI & CFI \\
\hline 1 & three-factor model & 1.621 & 0.065 & 0.973 & 0.970 & 0.973 \\
2 & two-factor model 1 & 2.398 & 0.087 & 0.919 & 0.910 & 0.918 \\
3 & two-factor model 2 & 6.139 & 0.160 & 0.724 & 0.694 & 0.723 \\
4 & one-factor model & 10.330 & 0.213 & 0.511 & 0.460 & 0.509 \\
\hline
\end{tabular}

\subsection{Hypothesis testing}

Main effects results. This study uses the method of hierarchical regression analysis to verify the hypothesis, as shown in Table 4, the gender, age, position, education and seniority as a control variable into the regression model. Then, the stepwise entry method is used to put the supervisor incivility into the regression model. As shown in Table 4 , the supervisor incivility was positively correlated with employee revenge significantly $(\beta=0.544, \mathrm{P}<$ 0.001, M2). Thus, Hypothesis 1 is supported.

Table 4 Regression analysis of direct effects

\begin{tabular}{llcc}
\hline \multicolumn{2}{c}{ Type of the Variable } & Employee Revenge & M2 \\
\cline { 2 - 3 } & gender & M1 & -.070 \\
& age & -.137 & -.012 \\
\multirow{4}{*}{ Control variable } & position & .038 & -.055 \\
& education & -.069 & -.042 \\
& work seniority & .030 & .007 \\
& supervisor incivility & 0.012 & $.544^{* * * *}$ \\
& $\mathrm{~F}$ & & 20.085 \\
& $\mathrm{R}^{2}$ & 1.902 & $.311^{* * * *}$ \\
& $\Delta \mathrm{R}^{2}$ & $.035^{* * * *}$ & .296 \\
\hline
\end{tabular}

Moderation results . As shown in table 5, supervisor incivility has a significant positive correlation to employee revenge $(\mathrm{M} 4, \beta=.544, \mathrm{P}<0.001)$, after entering the interactions term between supervisor incivility and employee revenge in model 6 , and the interaction coefficient is significant $(\beta=.340, \mathrm{P}<0.01), \mathrm{R}^{2}=.583(\mathrm{P}<0.001)$, Which indicate that hostile attribution play a positively moderating role between supervisor incivility and employee revenge.

Table 5 Moderated Regression Results

\begin{tabular}{|c|c|c|c|c|c|}
\hline \multirow{2}{*}{\multicolumn{2}{|c|}{ Type of the Variable }} & \multicolumn{4}{|c|}{ Employee Revenge } \\
\hline & & M3 & M4 & M5 & M6 \\
\hline & gender & -.137 & -.070 & -0.067 & -.071 \\
\hline & age & .038 & -.012 & -0.011 & -.012 \\
\hline control & position & -.069 & -.055 & 0.046 & -.056 \\
\hline \multirow[t]{2}{*}{ variable } & education & .030 & -.042 & 0.038 & -.036 \\
\hline & work seniority & .012 & .007 & 0.012 & .008 \\
\hline independent & SI & & $.544 * * *$ & $0.689 * * *$ & $.474 * * *$ \\
\hline moderator & $\mathrm{HA}$ & & & $0.026 * * *$ & $.136 * * *$ \\
\hline \multirow[t]{4}{*}{ Interaction item } & SI $\times$ HA & & & & $.340 * * *$ \\
\hline & $\mathrm{F}$ & 1.626 & 69.763 & 59.751 & 53.897 \\
\hline & $\mathrm{R}^{2}$ & $0.025 * * *$ & $0.575^{* * *}$ & $0.575 * * *$ & $0.583 * * *$ \\
\hline & $\Delta \mathrm{R}^{2}$ & 0.010 & 0.566 & 0.565 & 0.572 \\
\hline
\end{tabular}

Note. Supervisor incivility (SI), hostile attribution (HA) and employee revenge(ER)

To show and explain the moderating role of hostile attribution in the entire model, the study draws on widely used figure of the moderating role. According to the methods and procedures proposed by Aiken et al (1991), we draw figure of moderating role that the relationship of hostile attribution between supervisor incivility and employee revenge. We can see the extent to which from this figure, low hostile attribution (M-1SD) and high hostile attribution (M+1SD) have influence on employee revenge. As shown on Figure 1. 
Therefore, compared with the low hostile attribution, the employees with high hostile attribution can strengthen the relationship between supervisor incivility and employee revenge, and the hypothesis 2 is supported.

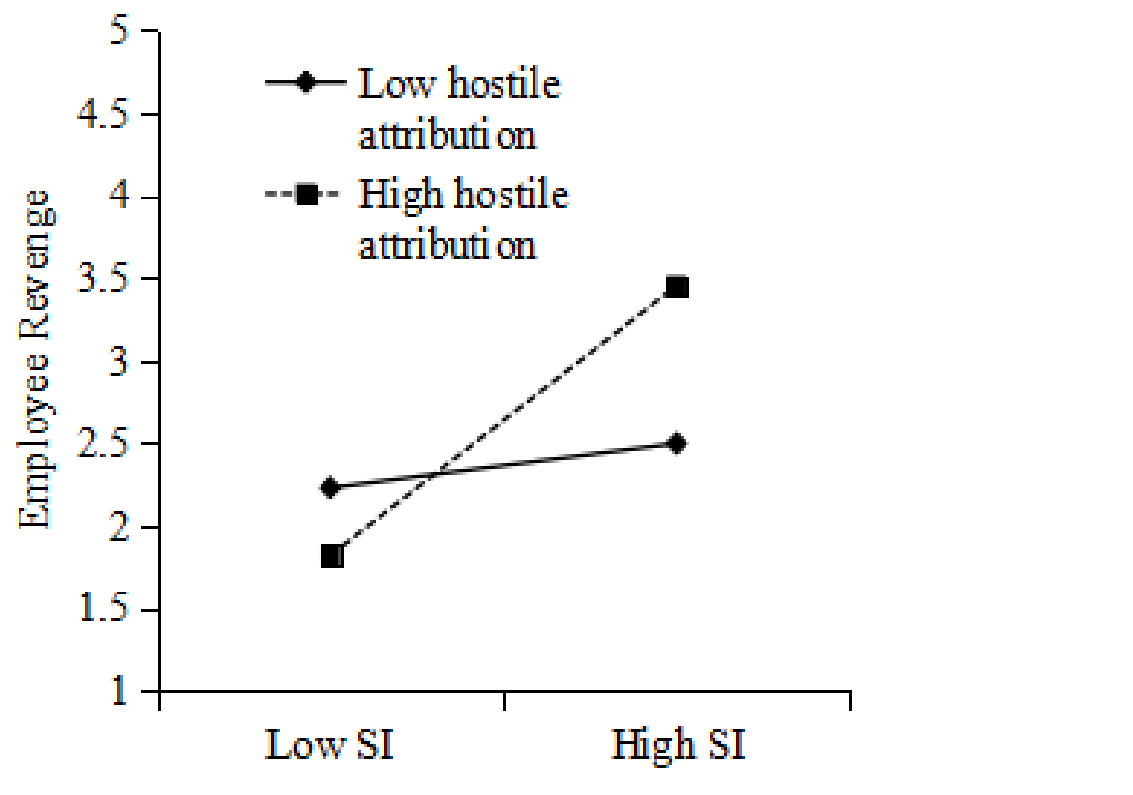

Figure 2 Hostile attributions as a moderator of the relationship

\section{Discussion}

This paper mainly focuses on the effect of supervisor incivility on employee revenge, especially on the moderator role of hostile attribution. It shows that:(1) supervisor incivility significantly has a positive effect on employee revenge;(2) hostile attribution moderates the main effect positively, such that the higher employees with hostile attribution, the stronger the association between supervisor incivility and employee revenge; the lower employees with hostile attribution, the weaker the association between supervisor incivility and employee revenge.

\subsection{Theoretical implications}

Our research mainly contributes to literature in two aspects. First, based on the norm of reciprocity, we explore the association between supervisor incivility and employee revenge. Our findings in support of supervisor incivility significantly have a positive effect on employee revenge. The study enriches the outcome of supervisor incivility. Second, due to the nascent stage of this area of research, little is known about the conditions that either strengthen or weaken the relationship between these constructs. Liu et al (2017a) showed that hostile attribution can lead to aggressive behavior and antisocial behavior of employees. Therefore, we take this variable as a moderator between supervisor incivility and employee revenge, which has an important influence on the employee's behavior. This study suggests that hostile attribution moderates the association between supervisor incivility and employee revenge. Hostile attribution is a negative attribution style. The findings of this study are helpful in understanding how the degree of employee hostility attribution affects the process of supervisor incivility and employee revenge in the context of Chinese culture. Meanwhile, it is of great significance to a comprehensive understanding of the individual attitudes and behaviors changes in workplace.

\subsection{Management implications}

The results of this study show that supervisor incivility has an obvious positive effect on employee revenge. Therefore, the organization should pay more attention to the leadership behavior (especially the destructive leadership). The organization can assess the supervisor regularly and get the assessment data through anonymous survey. It's suggested to conduct reward and punishment mechanism and put the leadership behavior into the performance appraisal system. In addition, when recruiting or promoting the managers, the organization should consider incivility as an important indicator. Meanwhile, the organization need pay more attention to train manager's communication skills and prevent the supervisor incivility. At the same time, we also point out that hostile attribution aggravates the association between supervisor incivility and employee revenge. Therefore, it is necessary to guide employees to establish correct cognition in the organization. 
For employees with high hostility attribution, the organization should conduct training interventions or carry out employee assistance programs, which can help them to correct their attitude, maintain an optimistic and positive attitude, actively seek ways to solve problems, and reduce the negative impact of superior incivility.

\subsection{Potential Limitations and Future Directions}

As with all research, our study has some limitations. First, we only collect the cross-sectional data and ignore the impact of time effects on variables, which makes it difficult to test the dynamic impact of supervisor incivility on employee revenge. But our hypothesis model agrees with the research conclusion, namely the leadership behavior can be used as a predictor of employee revenge.

The conclusion is consistent with the findings of negative side of leadership in organizations. The future researchers can use time series design, and through empirical sampling or field test method to collect horizontal and vertical data, which will make it more accurately to grasp the relationship among variables; second, it uses the single-source data measurement methods and the conclusions will be influenced easily by the deviation of common method. In this study, employee self-evaluation is used to obtain employee revenge data. However, employees are likely to consider their own face problems and have reservations in filling in questionnaire. Therefore, the other evaluation ways are more likely to restore the essence of employee revenge. In order to reduce measurement deviation, the suggestions of Podsakoff can be taken. Through protecting the privacy of interviewees, the concern to employees' evaluation will be lower. At the same time, confirmatory factor analysis was conducted on the data, and the results showed that there was a good distinction between the main variables. Therefore, future research can use multi-source or other assessment methods to obtain data to avoid the impact of homologous error.

\section{References}

Aiken, L. S., \& West, S. G. (1991). Multiple regression: testing and interpreting interaction, New bury Park: Sage. Andersson, L. M., \& Pearson, C. M. (1999). Tit for tat? The spiraling effect of incivility in the workplace [J]. Academy of Management Review,24(3):452-471.

Aquino, K., Tripp, T. M., \& Bies, R. J. (2001). How employees respond to personal offense: The effects of blame attribution, victim status, and offender status on revenge and reconciliation in the workplace. Journal of Applied Psychology, 86(1): 52-59.

Caza, B. B., \& Cortina, L. M. (2007). From insult to injury: Explaining the impact of incivility. Basic and Applied Social Psychology, 29(4): 335-350.

Coffin, B. (2003). Breaking the silence on white collar crime. Risk Management,50(2): 8-10.

Cortina, L. M., \& Magley, V. J. (2001). Incivility in the workplace:Incidence and impact. Journal of Occupational Health Psychology, 6(1): 64-80.

Cortina, L. M., \& Magley, V. J. (2009). Patterns and profiles of response to incivility in the workplace[J].Journal of Occupational Health Psychology,14(3):272-288.

Dupre, K. E., \& Barling, J. (2006). predicting and preventing supervisory workplace aggression [J].Journal of Occupational Health Psychology,11(1):13-26.

Ferguson, M. (2012). You cannot leave it at the office: Spillover and crossover of coworker incivility. Journal of Organizational Behavior,33(2): 571-588.

Ferrari, J. R., \& Emmons, R. A. (1994). Procrastination as revenge: Do people report using delays as a strategy for vengeance? Personality and Individual Differences, 17(4): 539-544.

Frijda, N. H. (1994). The lex talionis: On vengeance. In T. van Goozen, N. van de Poll, \& J. Sargeant (Eds.), Emotions: Essays on emotion theory). New York, NY: Psychology Press.

Gouldner, A. W. 1960. The norm of reciprocity: A prelimmary statement. American Sociological Review, 25(3):161-178.

Guan, F. M. (2013). Research on Relationship between Workplace Incivility and Work Engagement. Shanghai: East China University of Science and Technology.

Helm, B., Bonoma, T V., \& Tedeschi, J, T., (1972). Reciprocity for harm done. Journal of Social Psychology, 87 (2): 89-98.

Lim, S., Cortina, L. M., \& Magley, V. J. (2008). Personal and workgroup incivility: Impact on work and health outcomes. Journal of Applied Psychology, 93(7): 95-107. 
Lim, V. K., \& Teo, T. S. (2009). Mind your E-manners: Impact of cyber incivility on employees' work attitude and behavior. Information \& Management, 46(8): 419-425.

Lim,S.,\&Lee,A. (2011). Work and nonwork outcomes of workplace incivility: does family support help[J].Journal of Occupational Health Psychology, 16(1): 95-111.

Liu, C. E., \& Dai, W. W. (2012). A literature review on workplace incivility. Chinese Journal of Management, 9(7):1092-1097.

Liu, C. E., \& Liu, F. (2011). An empirical study on the relationship between workplace incivility, job satisfaction and turnover intention. Journal of Hunan University of Commerce, 18(2): 76-79.

Liu, C. E., Chen, Y.H., \& Yu, S.X., (2017b). Supervisor Incivility, Psychology Safety and Employee Turnover Intention: Does Supervisor-Subordinate Guanxi Matter? International Journal of Business and Social Science, 8(9): 79-90.

Liu, C. E., Hu, S. M., Yu, S. X., Chen, Y.H., \& Huang, J. (2017a). Supervisor Incivility is Related to Employee Creativity: A Locus of Control Explanation of the Mediated Relations. Chinese Journal of Management, 14(9):1315-1323.

Liu, C. E., Huang, J., \& Xie, W. (2018). The Effect of Supervisor Incivility on Employee Creativity: A ChinMediation Model. Jiangsu Social Sciences, 39(3): 165-174.

Miller, D. T. (2001). Disrespect and the experience of injustice. Annual review of psychology, 52(1): 527-553.

Miner, K. N., Settles, I. H., Pratt-Hyatt, J. S., \& Brady, C. C. (2012). Experiencing incivility in organizations: The buffering effects of emotional and organizational support. Journal of Applied Social Psychology,42(5): 340-372.

Mitchell, M. S., \& Ambrose, M. L. Abusive supervision and workplace deviance and the moderating effects of negative reciprocity beliefs[J]. Journal of Applied Psychology, 2007, 92 (4): 1159-1168.

Penney, L. M., \& Spector, P. E. (2005). Job stress, incivility, and counterproductive work behavior (CWB): The moderating role of negative affectivity. Journal of Organizational Behavior, 26(1): 777-796.

Porath, C., \& Pearson, C. (2013). The price of incivility. Harvard business review, 91(1-2): 114-121.

Robinson, S. L., \& Bennett, R. J. (1995). A typology of deviant workplace behaviors: A multidimensional scaling study. Academy of Management Journal, 38(1): 555-572.

Sakurai, K., \& Jex, S. M. (2012). Coworker incivility and incivility targets' work effort and counterproductive work behaviors: The moderating role of supervisor social support. Journal of Occupational Health Psychology, 17(4): 150-161.

Skarlicki, D. P., \& Folger, R. (1997). Retaliation in the workplace: The roles of distributive, procedural, and interactional justice. Journal of applied Psychology, 82(3): 434-443.

Sliter, M., Sliter, K., \& Jex, S. (2012). The employee as a punching bag: The effect of multiple sources of incivility on employee withdrawal behavior and sales performance. Journal of Organizational Behavior, 33(5): 121-139.

Spector, P. E., Fox, S., Penney, L. M., Bruursema, K., Goh, A., \& Kessler,S. (2006). The dimensionality of counterproductivity: Are all counterproductive behaviors created equal? Journal of Vocational Behavior, 68(3): 446-460.

Tepper, B. J., Duffy, M. K., Henle, C. A., \& Lambert, L. S. (2006). Procedural injustice, victim precipitation, and abusive supervision. Personnel Psychology, 59(1): 101-123.

Thau, S., Bennett, R. J., Mitchell, M.S, \& Marrs, M. B. (2009). How management style moderates the relationship between abusive supervision and workplace deviance: an uncertainty management theory perspective. Organizational Behavior and Human Decision Processes, 108(1): 79-92.

Vardi, Y., \& Weitz, E. (2004). Misbehavior in organizations: Theory, research and management. Mahwah, NJ: Erlbaum.

Zhang, G. L. (2009). The relationship between organizational justice and employee retaliation behavior. Jinan: Shandong University.

Zhou, H., \& Long, L. R. (2004). Statistical remedies for common method biases. Advances in Psychological Science, 12(6): 942-950. 